\title{
Crop rotations that integrate pasture are less vulnerable to nitrogen leaching due to changes in microbial community composition and reduced nitrification
}

Jeth GV Walkup

jgwalkup@mix.wvu.edu

Follow this and additional works at: https://researchrepository.wvu.edu/etd

Part of the Environmental Microbiology and Microbial Ecology Commons

\footnotetext{
Recommended Citation

Walkup, Jeth GV, "Crop rotations that integrate pasture are less vulnerable to nitrogen leaching due to changes in microbial community composition and reduced nitrification" (2018). Graduate Theses, Dissertations, and Problem Reports. 3696.

https://researchrepository.wvu.edu/etd/3696

This Thesis is protected by copyright and/or related rights. It has been brought to you by the The Research Repository @ WVU with permission from the rights-holder(s). You are free to use this Thesis in any way that is permitted by the copyright and related rights legislation that applies to your use. For other uses you must obtain permission from the rights-holder(s) directly, unless additional rights are indicated by a Creative Commons license in the record and/ or on the work itself. This Thesis has been accepted for inclusion in WVU Graduate Theses, Dissertations, and Problem Reports collection by an authorized administrator of The Research Repository @ WVU. For more information, please contact researchrepository@mail.wvu.edu.
} 


\title{
Crop rotations that integrate pasture are less vulnerable to nitrogen leaching due to changes in microbial community composition and reduced nitrification
}

\author{
Jeth Walkup \\ Thesis submitted to the \\ Davis College of Agriculture, Natural Resources and Design \\ at West Virginia University \\ in partial fulfillment of the requirements for the degree of \\ Master of Science in Applied and Environmental Microbiology \\ Ember Morrissey, Ph.D., Chair \\ James Kotcon, Ph.D. \\ Zachary Freedman, Ph.D.
}

Division of Plant and Soil Sciences

Morgantown, West Virginia

2018

Keywords: Agroecology, Ammonia Oxidizing Archaea, Nitrification, N Immobilization, Pasture Integrated Crop Rotation

Copyright 2018 Jeth Walkup 


\section{Abstract \\ Crop rotations that integrate pasture are less vulnerable to nitrogen leaching due to changes in microbial community composition and reduced nitrification}

\section{Jeth Walkup}

Agroecosystems occupy a large portion of the United States and receive a disproportionally high amount of terrestrial nitrogen inputs. As application rates increase, nitrogen use efficiency declines and yield return decreases, leading to higher rates of nitrogen loss, contributing to greater environmental problems. Nitrogen limitation in natural ecosystems leads to tight nitrogen cycling and low potential for loss, but the excessive concentrations of nitrogen in agricultural soils amplifies the significance of microbially mediated processes like nitrification. In order to develop sustainable agricultural practices, the long-term effects of management practices on the soil microorganisms that perform central roles in the transformation of nitrogen need to be studied. To study the long-term impacts of compost application and pasture integration in crop rotation, samples were collected from the existing Organic Crop Livestock Field (OCLF) experiment on the WVU organic research farm. The 19year-old OCLF experiment has a traditional four-year rotation of corn, soybeans, wheat and kale/rape, and a pasture integrated seven-year rotation of the four crops followed by three years spent in orchard grass/red clover pasture, each with compost amended and no-input control treatments. The compost-input and pasture integrated rotation treatments increased soil organic matter, respiration, and extracellular enzyme activity, suggesting enhanced soil microbial activity. Soil prokaryotic community composition was affected by the long-term treatments, including compost driven increases in the abundance of ammonia oxidizing organisms (AOO), but the pasture integration diminishes this increase. Similarly, the compost addition led to rapid ammonification, higher rates of potential nitrification, and higher concentrations of nitrate early in the season, but these effects were greatly mitigated by the pasture integration. The rate of nitrification was correlated with the abundance of AOO, indicating the importance of this group of organisms to the nitrogen cycle and highlights the connection between nitrification, ammonium availability, and community composition and function. This link between nitrifier abundance, nitrification rates, and nitrate levels indicates that the long-term integration of pasture in crop rotation has the potential to reduce nitrogen leaching early in the growing season. As crop yields were unaffected by pasture integration, this management practice could reduce the potential for negative environmental impacts without reducing productivity. 


\section{Acknowledgement}

I thank my advisor, Dr. Ember Morrissey, for the opportunity to pursue research inspired by my own interests under her guidance and support. I am thankful to be a member of her lab, and I am appreciative of my fellow lab mates, Chansotheary Dang, Rene Miller, Logan Webb, Nate Beck, and April Kessel, for their company and the assistance they have lent me. I would also like to thank my committee members, Dr. James Kotcon and Dr. Zachary Freedman, for their input, encouragement, and direction. Lastly, I would like to thank my wife, Sarah Walkup, for her tireless support and feigned interest in my sometimes senseless passion for things that live in the soil. 


\section{Table of Contents}

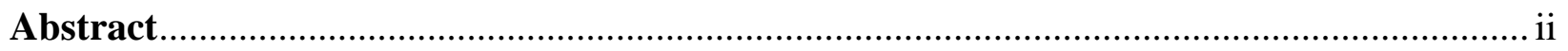

Acknowledgement ………………………………..................................................... ii

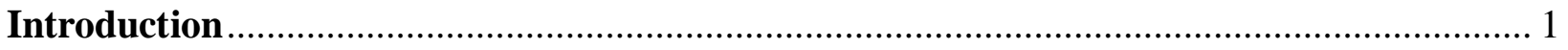

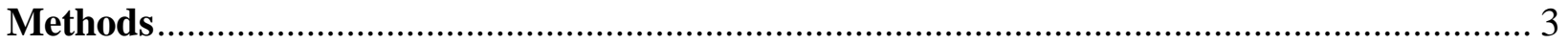

Site and sample collection ....................................................................................... 3

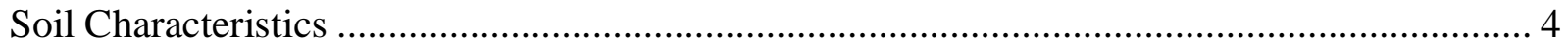

Soil prokaryotic community composition and abundance...................................................... 5

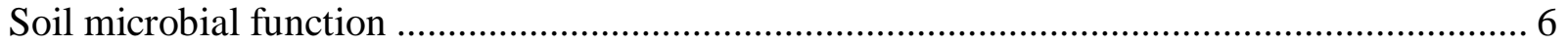

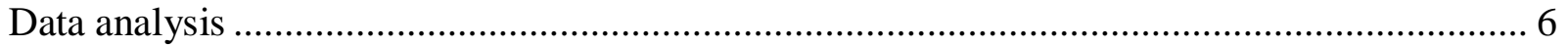

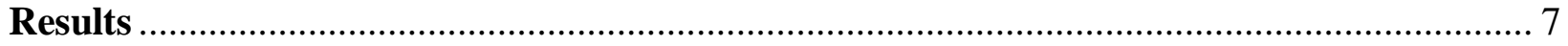

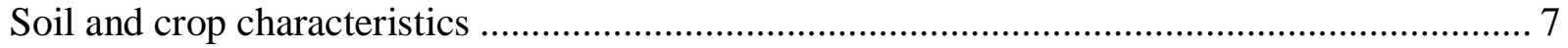

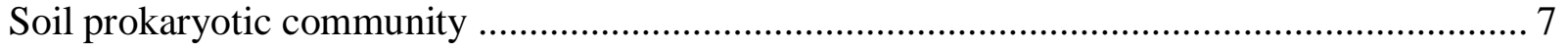

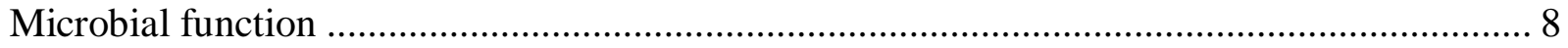

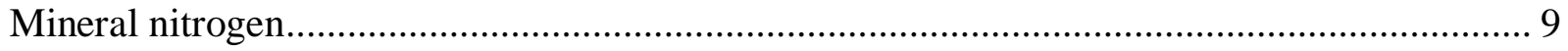

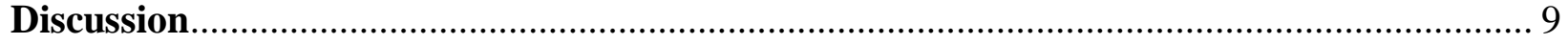

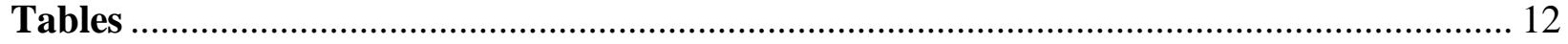

Table 1: Soil and crop characteristics ............................................................................ 12

Table 2: Potential extracellular enzyme activity ……………............................................. 13

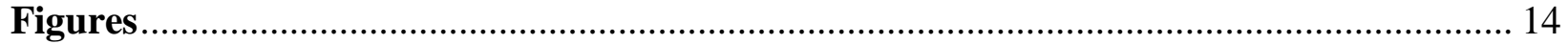

Figure 1: Prokarytic community analysis ......................................................................... 14

Figure 2: Prokaryote, AOO, and NOB abundance ………................................................ 15

Figure 3: Soil respiration and nitrification ....................................................................... 16

Figure 4: Soil mineral nitrogen concentrations ................................................................. 17

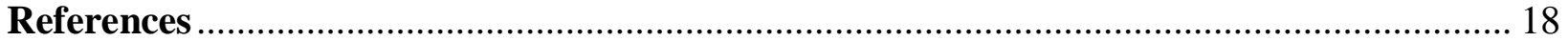

Appendix 1. Miscanthus residue amendment experiment. ....................................................... 23 


\section{Introduction}

Management of nitrogen in agricultural systems reflects the competing needs of a growing population and a conscious effort to care for the environment. Nitrogen inputs to agricultural fields in the US increased from less than 3 million tons in 1960 to over 13 million tons in 2013. This is attributable to an expansion of agricultural land and higher rates of nitrogen application, which have approximately doubled over the same period to the current rate of $\sim 140$ pounds per acre (USDA ERS, 2013). Agricultural land occupies 915 million acres, almost 50\% of the land in the contiguous US, of which 390 million acres are croplands (USDA NRCS, 2012), leading to a very high rate of nitrogen loading over a large portion of the country. Nitrogen inputs to agricultural systems in the form of fertilizer and cultivated nitrogen-fixing plants are the primary source of nitrogen to terrestrial environments in the United States, amounting to approximately 1.5 times the input from naturally occurring nitrogen fixation and atmospheric deposition on the rest of the country (EPA, 2011). Despite high crop demand, intensively grown crops may take up only 40-60\% of the nitrogen applied in a growing season, with higher nitrogen loss associated with increased application rate (Lassaletta et al. 2014; Drinkwater and Snap, 2007). Increased application rates have led to higher yields but diminishing returns have resulted in decreased nitrogen use efficiency and nitrogen that remains in the soil is vulnerable to loss through erosion, gaseous loss of denitrification products, or nitrate $\left(\mathrm{NO}_{3}{ }^{-}\right)$leaching, leading to drinking water contamination and eutrophication (Nolan et al. 2002). As concerns for environmental impacts of $\mathrm{N}$ pollution meet the desire to maintain high yields, research must focus on maximizing nitrogen use efficiency in agroecosystems through better management practices.

The form and availability of nitrogen in soil is mediated by a complex interaction between the soil microorganisms and the environmental conditions (Benoit et al. 2014; Jabloun et al. 2015). Most of the nutrients in agroecosystems are introduced in the form of fertilizers and amendments (e.g. compost and manure) which are acted on by microorganisms. The soil organic matter (SOM) pool, which is mostly composed of decomposed microbial biomass and plant detritus (Schmidt et al. 2011), is also an important source of nitrogen but is only available for plant uptake following microbial decomposition. Decomposition processes are dependent on the activity of the soil microbial heterotrophs, which respond to management practices. For instance, 
organic amendments produce changes in microbial community composition (Cedarlund et al. 2014) and increase microbial biomass and soil activity rates relative to chemical fertilizers (Tu et al. 2006; Liu et al. 2007). Farm soils amended with organic sources of nitrogen demonstrate higher enzyme activity than fields fertilized with synthetic fertilizers (Bandick and Dick 1999; Marinari et al. 2006). In contrast high synthetic nitrogen application can decrease diversity within soil bacterial communities (Zeng et al. 2016; Zhou et al, 2017) and decrease the activity of enzymes associated with nitrogen acquisition and lignin degradation (Sinsabaugh et al. 2002). This past work demonstrates the close association between microbial communities, decomposition processes, and nitrogen cycling dynamics in agroecosystems.

The incorporation and rapid decomposition of nitrogen-rich amendments such as compost and manure in the spring could cause much of the nitrogen in these organic amendments to be lost from the system before the crops have demand for biomass production. The period between the application of nitrogen sources and crop uptake of nutrients may be several weeks, and mineral nitrogen available during this period is vulnerable to loss, especially under wet soil conditions (Jabloun et al. 2015). Carbon inputs to soil may help increase nitrogen use efficiency by preventing loss of nitrogen early in the season. When carbon is added with nitrogen, such as in the case of legumes (Drinkwater, 1988) or manure (Di and Cameron. 2002), $\mathrm{NO}_{3}{ }^{-}$leaching losses are reduced relative to synthetic fertilizer. Organic management systems that increase soil organic matter inputs, such as green manures and catch crops, exhibited less potential for leaching than an organic system that fertilized with manure and a conventionally fertilized system (Thorup-Kristenson et al. 2012). These reductions in nitrogen loss associated with carbon inputs likely result from microbial nitrogen immobilization by heterotrophic bacteria preventing the accumulation of $\mathrm{NH}_{4}{ }^{+}$, its conversion into $\mathrm{NO}_{3}{ }^{-}$by nitrifiers, and loss from the system via leaching, however few studies provide conclusive evidence for this mechanism.

Pasture integration into crop rotations may introduce carbon-rich substrates for microbial decomposition. Perennial pasture species allocate half or more of their biomass below ground (Boot et al. 1990) and can increase soil organic carbon contents over time (McLauchlan et al. 2006), including increases in organic matter in incorporation into crop rotation (Pena et al. 2017). Consequently, this management practice may stimulate nitrogen immobilization by soil heterotrophs, especially when pasture is tilled into the soil prior to crop production, potentially 
limiting losses from nitrogen fertilizer. However, the scarcity of experiments designed to test the long-term effects of pasture integration in crop rotation means that the effects of this management practice on microbial communities and nitrogen cycling dynamics is poorly understood.

The objectives of this research were to investigate how long-term management practices of compost addition and pasture integration impact microbial community composition and affect mineralization and nitrification. We hypothesized that pasture integration would make nitrogen from compost less vulnerable to leaching early in the growing season by altering soil heterotroph biodiversity, stimulating decomposition, and reducing nitrifier abundance and activity. To test this mechanism, we collected soil from a long term field experiment and measured abundance and diversity of soil prokaryotes along with their rates of soil respiration, enzyme activity, and nitrification during field preparation and crop establishment.

\section{Methods}

Site and sample collection

Soil samples were collected from a subset of plots in the Organic Crop Livestock Farm (OCLF) Experiment on the West Virginia University Plant and Soil Sciences research farm (Pena et al., 2017; Romano et al. 2017). The OCLF experiment is a crop plot experiment started in 1999 to test the long term effects of compost addition and pasture integrated crop rotation in an organic cropping system. The experimental design is based on a four-year crop rotation of corn, soybeans, wheat, and a brassica, followed by a summer cover crop of cowpea and a winter mixed cover crop of rye and vetch. Management of the experiment follows current best management practices, including annual soil testing and treatment with agricultural lime to manage $\mathrm{pH}$. The experiment includes three $\sim 1800 \mathrm{ft}^{2}$ plots of each crop under each experimental treatment planted every year.

The experiment manipulates compost addition and pasture integration in a full factorial design. The compost amended treatment plots are planted in the same four-year rotation and amended with composted dairy manure equivalent to $45 \mathrm{Mg} \mathrm{Ha}^{-1}$ incorporated with cover crops in the spring in years that the plots are planted with maize or wheat. The pasture integrated crop rotation treatment includes the same four-year crop rotation, but instead of cover crops the plots 
are planted with orchard grass and red clover as pasture for three years. These two treatments are implemented on plots separately and together to test their individual influences as well as potential interactions producing four treatments: Control, compost amended, pasture integrated, and compost amended pasture integrated. Plots not receiving compost may acquire $\mathrm{N}$ from biological $\mathrm{N}$ fixation associated with legumes in the rotation (soybean, red clover, and hairy vetch). Compost additions to compost and pasture treatment plots occur in the years that maize or wheat are grown, as in the compost treatment, which leads to a lower compost application rate over the course of the full seven-year rotation relative to the four-year compost rotation.

Samples were collected six times over the course of the growing season from the twelve plots that were planted with corn in the spring of 2017, with sampling times corresponding to benchmarks in the preparation for and growth of the corn crop. Sampling occurred on May $9^{\text {th }}$, before tillage and incorporation of cover crops or pasture, May $23^{\text {rd }}$, after tillage and incorporation of cover crops and pasture, June $12^{\text {th }}$, after seed bed preparation and seeding, June $26^{\text {th }}$, after seedling emergence, July $10^{\text {th }}$, at the point in crop growth when nutrient acquisition changes from seed endosperm to soil nutrients, and July $20^{\text {th }}$, the point in crop growth when the plants reach peak nutrient uptake. At each sampling time 10 soil cores $10 \mathrm{~cm}$ deep and $5 \mathrm{~cm}$ in diameter were sampled from each plot in a random pattern. All ten cores were homogenized immediately and a $\sim 5 \mathrm{~g}$ subsample for DNA extraction was stored on ice for transportation to the lab.

\section{Soil Characteristics}

Soil moisture, field capacity, $\mathrm{pH}$, and redox potential were immediately measured upon return to lab. Soil moisture was calculated from the loss of mass from a soil subsample after drying for 24 hours at $100^{\circ} \mathrm{C}$. Field capacity was measure according to Veihmeyer and Hendrickson (1949) by weighing soil samples before and after filling all pore space with water and allowing complete drainage under gravity. Percent soil organic matter (SOM) was estimated from mass loss on ignition at $500^{\circ} \mathrm{C}$ for 5 hours. Carbon and nitrogen content were analyzed by combustion in a Vario MAX cube (Elementar, Ronkonkoma, NY). Redox potential and pH were analyzed with a Mettler Toledo FiveGo pH/mV probe (Mettler Toledo, Columbus, OH). Clip samples of pasture and cover crops were collected by removing all live vegetative biomass from the soil surface from 3 random $450 \mathrm{~cm}^{2}$ subsamples, dried at $90^{\circ} \mathrm{C}$, and weighed to estimate 
aboveground biomass. Soil ammonium $\left(\mathrm{NH}_{4}{ }^{+}\right)$and nitrate $\left(\mathrm{NO}_{3}{ }^{-}\right)$concentrations were measured colorimetrically according to Hart (1994) and Miranda et al. (2001) on a Biotek Synergy HTX Multi-Mode MicroPlate Reader (BioTek Instruments Inc., Winooski, VT).

\section{Soil prokaryotic community composition and abundance}

Prior to DNA extraction, 20 ng of Halobacterium salinarum genomic DNA was added to $0.25 \mathrm{~g}$ of each soil sample to provide a known quantity of an internal standard in order to calculate absolute abundance of soil prokaryotes according to Smets et al. (2015). DNA was extracted from the $0.25 \mathrm{~g}$ subsample using the DNeasy PowerSoil Kit (Qiagen, Hilden, Germany) according to manufacturer's protocol. DNA concentration was measured using PicoGreen fluorescence assay (Molecular Probes, Inc., Eugene, OR). The total number of bacterial 16S rRNA and gene copies in each density fraction were determined by qPCR. All fractions were analyzed in triplicate in $15 \mu \mathrm{L}$ reactions. The reactions $(15 \mu \mathrm{L})$ consisted of $2 \mu \mathrm{L}$ of DNA template and $13 \mu \mathrm{L}$ of master mix. Reactions consisted of $2 \mu \mathrm{L}$ of DNA template, 0.2 $\mu \mathrm{M}$ forward (515F 5'-- GTGYCAGCMGCCGCGGTAA--3') and reverse (806R 5'-GGACTACNVGGGTWTCTAAT--3') primers (Caporaso et al., 2011), 7.5 $\mu$ L Syber Green Master Mix (BIO-RAD, Hercules, CA, USA) and molecular grade water. Thermal cycling conditions were denaturation at $95^{\circ} \mathrm{C}$ for 2 minutes, followed by 40 cycles of $95^{\circ} \mathrm{C}$ for 30 seconds, $55^{\circ} \mathrm{C}$ for 30 seconds and $72^{\circ} \mathrm{C}$ for 60 seconds. Prokaryotic $16 \mathrm{~S}$ rRNA genes were sequenced using Illumina adapted 515F and 806R 16S rRNA primers according to the Schloss lab protocol (Kozich, et al. 2013). Amplification products were batch normalized with the Invitrogen SequealPrep DNA normalization plates. The products recovered were pooled and cleaned using Ampure XP magnetic beads. The pools were quality checked and quantified with Thermo Fischer Qubit dsDNA HS (Waltham, MA, USA), Agilent Bioanalyzer DNA 1000 (Santa Clara, CA, USA) and Kapa Illumina Library Quantification qPCR assays (Boston, MA, USA). Individual pools were loaded onto a MiSeq standard v2 flow cell and sequenced in a 2x250bp paired end format that utilized a MiSeq v2 500 cycle reagent cartridge. Index 1 primers were added to appropriate wells and complemented the bacterial 16S-V4 primers 515F/806R. Illumina Real Time Analysis (RTA) v.1.18.54 was used for base calling and RTA output was demultiplexed and converted to FastQ format with Illumina Bcl2fastq v2.19.1. 


\section{Soil microbial function}

To estimate soil activity, soil respiration was measured using the closed chamber method (Bekku et al. 1995). Briefly, $100 \mathrm{~g}$ dry soil was measured into a Mason jar and wetted to $60 \%$ field capacity. Samples were incubated in sealed jars and the $\mathrm{CO}_{2}$ concentration of $10 \mathrm{~mL}$ of headspace was measured after 0, 24, and 48 hours on a LI-COR 6400XT (LI-COR Biosciences, Lincoln, Nebraska). These measurements were used to calculate the $\mu$ grams $\mathrm{C}$ respired g-soil ${ }^{-1}$ over the period of the incubation, with which we could calculate a respiration rate. Potential nitrification was estimated according to Hart (1994). Briefly $7.5 \mathrm{~g}$ soil was suspended in $50 \mathrm{~mL}$ of $0.75 \mathrm{mM}\left(\mathrm{NH}_{4}\right)_{2} \mathrm{SO}_{4}, 0.3 \mathrm{mM} \mathrm{KH} 2 \mathrm{PO}_{4}, 0.7 \mathrm{mM} \mathrm{K}_{2} \mathrm{HPO}_{4}$ solution and incubated at room temperature on an orbital shaker for 6 hours. Samples of solution were collected every 2 hours and $\mathrm{NO}_{3}{ }^{-}$concentration was measured colorimetrically (as described above). Within 1 week of sampling, potential extracellular enzyme activities (EEA) of $\beta-1-4$ glucosidase (BG), 1-4- $\beta$ cellobiosidase $(\mathrm{CBH})$, and L-leucine aminopeptidase (LAP) were measured using a fluorimetric microplate assay as described in Neubauer et al. (2013), with the following modifications: soils were added to distilled water, sonicated for 2 minutes, and fluorescence emissions were read every hour for 6 hours on a Biotek Synergy HTX Multi-Mode MicroPlate Reader (BioTek Instruments Inc., Winooski, VT). BG and CBH activity was measured using Methylumbelliferone (MUB- linked substrate and LAP was measured using 7-amino-4methylcoumarin (AMC)-linked substrate.

\section{Data analysis}

All data were analyzed using R 3.3.2 (R Core Team 2016). Variables that did not change significantly over time were averaged across all times for each plot. Differences in crop and soil characteristics, soil respiration, nitrification rates, extracellular enzyme activity, ammonium and nitrate concentrations, $\log _{10}$-transformed gene abundance, and absolute abundance of ammonia and nitrite oxidizing organisms were analyzed using a repeated measures Analysis of Variance (ANOVA) with compost amendment and pasture integration as factors with an $\alpha$-value of 0.05 . Post Hoc differences of means were analyzed using Tukey's Honestly Significant Difference. Differences in the relative abundance of prokaryotic phyla were similarly analyzed with ANOVA except with a more conservative significance cutoff $(\alpha=0.001)$ due to multiple comparisons. Prokaryotic sequences were processed in MacQiime 1.9.1 according to McHugh 
and Schwartz (2016), with the exception of using the SILVA database. Briefly, paired end reads were joined and open reference operational taxonomic units (OTUs) were picked by 97\% identity using SILVA v128 as the database. OTUs that represented less than $0.005 \%$ of the total sequence count were filtered out, and samples were rarefied at 25,796 reads per sample, which included all but one of the samples in the analysis. Weighted UniFrac dissimilarity matrix was used to create a principal coordinate analysis (PCoA). The prokaryotic community composition was analyzed using Permutational Multivariate Analysis of Variance (PerMANOVA) with compost amendment, pasture integration, and time as factors.

\section{Results}

\section{Soil and crop characteristics}

Compost addition significantly increased organic matter (Table 1). Although not significant, soil organic matter tended to be higher with pasture integration relative to the control soils. Field capacity was increased by both the compost addition and the pasture integration, with the control soil significantly lower than the other three management soils. Neither soil moisture nor $\mathrm{pH}$ were significantly different among the treatments. The end of season maize yield and plant height was significantly higher in compost amended plots regardless of pasture integration (Table 1).

\section{Soil prokaryotic community}

The soil prokaryotic community composition was interactively affected by compost amendment and pasture-integration over time (Fig 1). The largest effect was from compost (PerMANOVA, pseudo-F = 25.25, $\mathrm{p}<0.001$ ), which can be visualized using PCoA. Compost amendment produced a shift to the left on PCoA Axis 1 and a shift down along PCoA Axis 2 (Fig. 1a). Compost amendment increased the relative abundance of the Bacteroidetes, and $\gamma-$ Proteobacteria, but decreased the proportion of Verrucomicrobia and Gemmatimonadetes (Fig. $1 b$, all $\mathrm{p}<0.001)$. The change in community due to pasture integration was less dramatic (PerMANOVA, pseudo-F = 10.46, p<0.001); however, pasture integration increased relative abundance of Verrucomicrobia ( $\mathrm{p}<0.001)$. The proportion of Chloroflexi was interactively affected, it was reduced by 19-24 \% when pasture and compost were applied independently but only $\sim 9 \%$ when applied in combination $(\mathrm{p}<0.001)$. The relative abundance of several taxonomic 
groups changed over time during the early growing season, including Crenarchaeota, comprised entirely of ammonia oxidizing archaea (AOA) in these samples, Chloroflexi, Nitrospirae, WS3, and $\alpha$-proteobacteria.

Total prokaryotic abundance, estimated using the internal standard sequencing method (Smets et al. 2015) for measuring 16S rRNA gene abundance, was significantly increased by compost addition (Fig. 2a). Compost addition increased the abundance of putative ammonia oxidizing organisms (AOO) but this increase was partially mitigated by pasture integration (Fig. 2b). The population of ammonia oxidizers was dominated by Archaea in these soils, with ammonia oxidizing bacteria (AOB) representing approximately $0-5 \%$ of $\mathrm{AOO}$, with no significant effect of treatments on the ratio of AOA:AOB ( $p>0.05)$. The abundance of putative nitrite oxidizing bacteria (NOB) increased in response to compost amendment (Fig. 2c). Compost also significantly increased the abundance of $16 \mathrm{~S}$ rRNA genes as estimated using qPCR.

\section{Microbial function}

Microbial community function as measured by potential soil respiration, nitrification, and extracellular enzyme activity were influenced by both compost amendment and pasture integration dynamically over the early growing season. Soil respiration varied over the growing season and among long-term treatments (Fig. 3a). Both pasture integration and compost amendment increased respiration, with control soils remaining less active than the other treatments throughout the early growing season. Prokaryotic abundance (16S rRNA gene abundance) was positively correlated with soil respiration when measured via the internal standard sequencing method but not when measured using qPCR (Fig. 3b). Potential nitrification rates were interactively affected by compost amendment and pasture integration (Fig. 3c). Compost amendment increased potential nitrification rates, but pasture integration mitigated this increase early in the season. Potential nitrification rates were correlated with the absolute abundance of AOO as estimated using the internal standard method, however rates were not correlated with the relative abundance of these organisms (Fig. 3d). Effects of compost amendment and pasture integration on cellulose degrading (beta-glucosidase, cellobiohydrolase) and nitrogen acquisition (leucyl-aminopeptidase) enzyme activities were variable over time (Table 2). However, the activities of cellulose degrading enzymes were significantly enhanced 
by pasture integration and/or compost amendment at multiple sampling dates. Similarly, leucylaminopeptidase activity was increased significantly by pasture-integration and compost amendment toward the middle of the season (Julian Day 177-201) (Table 2).

\section{Mineral nitrogen}

Compost amendment produced a peak in soil ammonium shortly after incorporation (Julian Day 140) in plots without pasture integration (Fig 4). Similar spikes in soil nitrate were observed in soils without pasture integration, with particularly high concentrations in the composted amended soils at Julian Day 160 and both the compost and control treatments at Julian Day 177. The pasture integrated soils, even those receiving compost amendment, maintained comparatively low $\mathrm{NO}_{3}{ }^{-}$concentrations throughout the season.

\section{Discussion}

The experimental period of 18 years was long enough for changes to both the soil characteristics and the soil prokaryotic community to manifest in response to both the compost amendment and pasture integration. Organic matter and field capacity increased in response to compost amendment and showed a similar trend in response to pasture integration, indicating greater soil health and better crop growing conditions (Pagliai et al. 2004; Evanylo et al. 2008; Johnston 2009), consistent with other studies of long term effects of organic amendments (Diacono \& Montemurro, 2011; Russelle et al. 2007; Tracy \& Zhang, 2008).

The soil prokaryotic community composition was affected most by the compost amendment, including significant effects on phyla representing $31 \%$ of the prokaryotic population. Both pasture and compost had significant effects on Verrucomicrobia and Chloroflexi, individually and interactively, respectively. The relative abundance of Gemmatimonadetes and Verrucomicrobia decreased in the presence of higher nitrogen inputs when apart from the pasture integration, which is consistent with these groups' responses in similar studies (Cedarlund et al. 2014).

Although the observed changes in the prokaryotic community composition attributed to pasture integrated rotation were modest, the effect of both treatments on the functioning of the microbial community were substantial. The decomposition of the compost amendment was associated with enhanced mineral nitrogen in the soil, and this effect was hampered by pasture 
integration within the crop rotation (Fig. 4). Soil respiration significantly increased in response to the pasture, indicating a more active microbial community. This response in activity is not proportional to the soil organic matter content or the aboveground biomass tilled into the soil (Table 1). This suggests that pasture enhances the organic matter inputs to the soil through below ground biomass or root exudation. A separate study of the soils from the OCLF experiment showed that SOM increased from the beginning to the end of the three-year period spent in pasture (Pena et al. 2017). A study of root biomass growth in forage crops in eastern Canada found that root biomass doubled from the first to the second year of growth of perennial grasses and legumes, and that these forage crops had lower shoot to root ratios than annual crops (Bolinder et al. 2002). Additionally, a study of soil carbon stocks in crop rotations in temperate Australia found that soil carbon increased in crop rotations that included a pasture phase, compared to continuous crop production (Chan et al. 2011). The three years of orchard grass/red clover pasture integration in the OCLF experiment likely lead to the development of greater root biomass than the winter rye/vetch cover crops. Although only significant later in the season, the increased potential activity of extracellular enzymes in response to pasture indicates increased microbial effort to decompose inputs and acquire nutrients. The abundant available carbon from pasture likely stimulated microbial decomposition activity (Fig. 3a) potentially leading to $\mathrm{N}$ immobilization.

Both compost amended treatments included compost application at the same rate and time at the beginning of the season, but the compost only soils showed a peak in soil ammonium concentration within days of compost application, while soil ammonium concentrations increased more slowly in the pasture and compost treatment, peaking weeks after the application of the compost (Fig 4a). Similarly, compost amended soils exhibited rapid increases in nitrate concentration (Fig 4a). Nitrate concentration increased gradually in both pasture integrated treatment and control soils in the beginning of the season. This suggests that the immobilization of nitrogen from pasture derived $\mathrm{C}$ is not sustained throughout the entire growing season. As the labile carbon availability decreases, $\mathrm{N}$ cycling likely switches from immobilization to mineralization, and the nitrogen in the microbial biomass becomes available for plant uptake months after compost application and incorporation, when the plant demand for $\mathrm{N}$ is at its highest (Campietti and Vyn, 2012). 
The early season reduction in mineral $\mathrm{N}$ due to pasture integration did not affect crop yields. Compost increased yield, with no limiting effect from pasture (Table 1). Maize uptake of nitrogen does not begin until approximately two weeks after seedling emergence (Abendroth et al. 2011), which occurred approximately two months after incorporation of compost in the OCLF, so any mineral nitrogen in the soil prior to that point was vulnerable to nitrification and loss from the system. The risk of nitrate leaching is high in any agricultural system, including organic systems (Becel et al. 2014; Drinkwater \& Snap, 2007; Stopes et al. 2002; Pang \& Letey, 2000), and a key to reducing this risk is in timing nutrient availability with crop demand. The availability of nitrogen during the growing season is crucial to maintain yields, but excess mineral nitrogen outside of the active growing season is at risk for loss. Our results suggest that the pattern of immobilization and mineralization stimulated by pasture integration in crop rotation is favorable for farmers dependent on organic forms of fertilization. The combination of reduced ammonium availability and lower abundance of AOO contributes to greater potential for retention of nitrogen from organic sources. Additionally, pasture can develop soil structure and increase SOM, leading to improved stability and water infiltration and retention (Pena et al. 2017). Implementation of practices such as pasture integrated crop rotation can help managers to maintain yields while preserving soil health and preventing environmental damage. 


\section{Tables}

Table 1: Long term management effects on soil and crop characteristics (mean \pm standard error). Two-way ANOVA results are indicated as main effects of compost (C), or pasture (P), and an interaction (I) between these treatments. Superscripts indicate significantly different means (Tukey's HSD, $\alpha=0.05$ ) when an interaction was present.

\begin{tabular}{|c|c|c|c|c|c|c|c|}
\hline Treatment & $\begin{array}{c}\text { Organic } \\
\text { Matter (\%) }\end{array}$ & $\mathrm{pH}$ & $\begin{array}{l}\text { Field Capacity } \\
\left(\mathrm{g} \text { water } \mathrm{g} \mathrm{soil}^{-1} \text { ) }\right.\end{array}$ & $\begin{array}{c}\text { Soil Moisture } \\
\text { (\%) }\end{array}$ & $\begin{array}{c}\text { Aboveground } \\
\text { Biomass } \\
\left(\mathrm{Mg} \mathrm{Ha}^{-1}\right)\end{array}$ & $\begin{array}{l}\text { Maize Yield } \\
\text { (bushels } \mathrm{Ac}^{-1} \text { ) }\end{array}$ & $\begin{array}{c}\text { Maize Plant } \\
\text { Height (inches) }\end{array}$ \\
\hline Compost, Pasture & $8.04 \pm 0.19$ & $7.23 \pm 0.09$ & $0.8 \pm 0.02^{\alpha}$ & $43.69 \pm 1.71$ & $6.14 \pm 1.05$ & $153.4 \pm 35.9$ & $76.3 \pm 4.8$ \\
\hline Compost & $7.91 \pm 0.29$ & $7.26 \pm 0.08$ & $0.75 \pm 0.02^{\alpha}$ & $41.23 \pm 1.60$ & $7.07 \pm 1.11$ & $159.3 \pm 19.1$ & $102.1 \pm 11.2$ \\
\hline Pasture & $6.28 \pm 0.11$ & $7.21 \pm 0.10$ & $0.75 \pm 0.03^{\alpha}$ & $42.21 \pm 1.35$ & $4.43 \pm 0.54$ & $65.4 \pm 22.7$ & $71.3 \pm 5.2$ \\
\hline Control & $5.61 \pm 0.14$ & $7.4 \pm 0.10$ & $0.61 \pm 0.02^{\beta}$ & $45.42 \pm 2.59$ & $3.02 \pm 0.32$ & $62.5 \pm 13.0$ & $65.5 \pm 4.2$ \\
\hline ANOVA & $\mathrm{C}$ & & I & & $\mathrm{C}$ & $\mathrm{C}$ & $\mathrm{C}$ \\
\hline
\end{tabular}


Table 2: Potential extracellular enzyme activity (mean \pm standard error) of the enzymes beta-1-4glucosidase (BG), 1-4-betacellobiosidase (CBH), and L-leucine aminopeptidase (LAP) over time. Superscripts indicate significantly different means (Tukey's HSD, $\alpha=0.05$ ) between compost (uppercase letters), pasture (lowercase letters), and interaction of compost and pasture (Greek letters).

\begin{tabular}{cccccccc}
\hline & Time (Julian Day) & 129 & 143 & 156 & 177 & 191 & 201 \\
\cline { 3 - 8 } & Treatment & & \multicolumn{2}{c}{$\mathrm{pmol} \mathrm{hr}^{-1} \mathrm{~g} \mathrm{soil}^{-1}$} & & \\
\hline \multirow{4}{*}{$\mathrm{BG}$} & Compost, Pasture & $25.89 \pm 1.6$ & $10.23 \pm 2.55$ & $10.06 \pm 2.58$ & $24.21 \pm 1.68^{\alpha}$ & $30.49 \pm 1.62^{\mathrm{A}}$ & $19.84 \pm 3.28^{\alpha \beta}$ \\
& Compost & $20.52 \pm 7.4$ & $14.72 \pm 2.43$ & $14.89 \pm 2.31$ & $14.58 \pm 1.03^{\mathrm{\beta}}$ & $27.2 \pm 5.15^{\mathrm{A}}$ & $19.74 \pm 4.58^{\alpha \beta}$ \\
& Pasture & $16.67 \pm 5.52$ & $10.13 \pm 2.03$ & $12.51 \pm 3.84$ & $12.1 \pm 1.74^{\beta}$ & $17.63 \pm 4.58^{\mathrm{B}}$ & $27.53 \pm 3.79^{\alpha}$ \\
& Control & $14.47 \pm 2.54$ & $8.09 \pm 2.94$ & $6.5 \pm 2.09$ & $10.28 \pm 0.99^{\mathrm{\beta}}$ & $14.68 \pm 1.66^{\mathrm{B}}$ & $8.24 \pm 1.67^{\beta}$ \\
\hline \multirow{4}{*}{$\mathrm{CBH}$} & Compost, Pasture & $4.23 \pm 0.87$ & $1.91 \pm 0.1^{\mathrm{A}}$ & $1.57 \pm 0.17^{*}$ & $4.15 \pm 0.27^{\mathrm{A}}$ & $5.69 \pm 1.16^{\mathrm{a}}$ & $3.84 \pm 0.74^{\mathrm{a}}$ \\
& Compost & $2.86 \pm 1.36$ & $2.84 \pm 0.5^{\mathrm{A}}$ & $1.74 \pm 0.18^{*}$ & $2.53 \pm 0.22^{\mathrm{bA}}$ & $2.74 \pm 0.4^{\mathrm{b}}$ & $8.81 \pm 0.71^{\mathrm{b}}$ \\
& Pasture & $3.52 \pm 0.68$ & $1.56 \pm 0.15^{\mathrm{B}}$ & $1.98 \pm 0.4^{*}$ & $2.07 \pm 0.14^{\mathrm{aB}}$ & $3.27 \pm 0.5^{\mathrm{a}}$ & $3.75 \pm 0.27^{\mathrm{a}}$ \\
& Control & $3.91 \pm 1.02$ & $1.33 \pm 0.23^{\mathrm{B}}$ & $0.81 \pm 0.26^{*}$ & $0.93 \pm 0.06^{\mathrm{bB}}$ & $2.06 \pm 0.52^{\mathrm{b}}$ & $4.22 \pm 1.8^{\mathrm{b}}$ \\
\hline \multirow{4}{*}{$\mathrm{LAP}$} & Compost, Pasture & $7.56 \pm 0.91^{\mathrm{A}}$ & $4.81 \pm 0.74$ & $5.46 \pm 0.5$ & $9 \pm 0.44^{\mathrm{aA}}$ & $10.61 \pm 1.16^{\mathrm{aA}}$ & $4.87 \pm 0.8^{\mathrm{A}}$ \\
& Compost & $6.3 \pm 2.39^{\mathrm{A}}$ & $7.64 \pm 0.6$ & $6.17 \pm 0.9$ & $5.93 \pm 0.55^{\mathrm{bA}}$ & $6.85 \pm 0.9^{\mathrm{bA}}$ & $5.25 \pm 0.6^{\mathrm{A}}$ \\
& Pasture & $3.02 \pm 1^{\mathrm{B}}$ & $4.22 \pm 0.73$ & $5.89 \pm 2.04$ & $4.41 \pm 0.32^{\mathrm{aB}}$ & $6.33 \pm 0.61^{\mathrm{aB}}$ & $3.94 \pm 0.58^{\mathrm{B}}$ \\
& Control & $3.53 \pm 0.48^{\mathrm{B}}$ & $6.28 \pm 2.67$ & $3.97 \pm 1.64$ & $4.12 \pm 1.14^{\mathrm{bB}}$ & $5.28 \pm 0.1^{\mathrm{bB}}$ & $2.39 \pm 0.43^{\mathrm{B}}$ \\
\hline
\end{tabular}

* significant interaction effect but non-significant difference of means according to Tukey's HSD. 


\section{Figures}
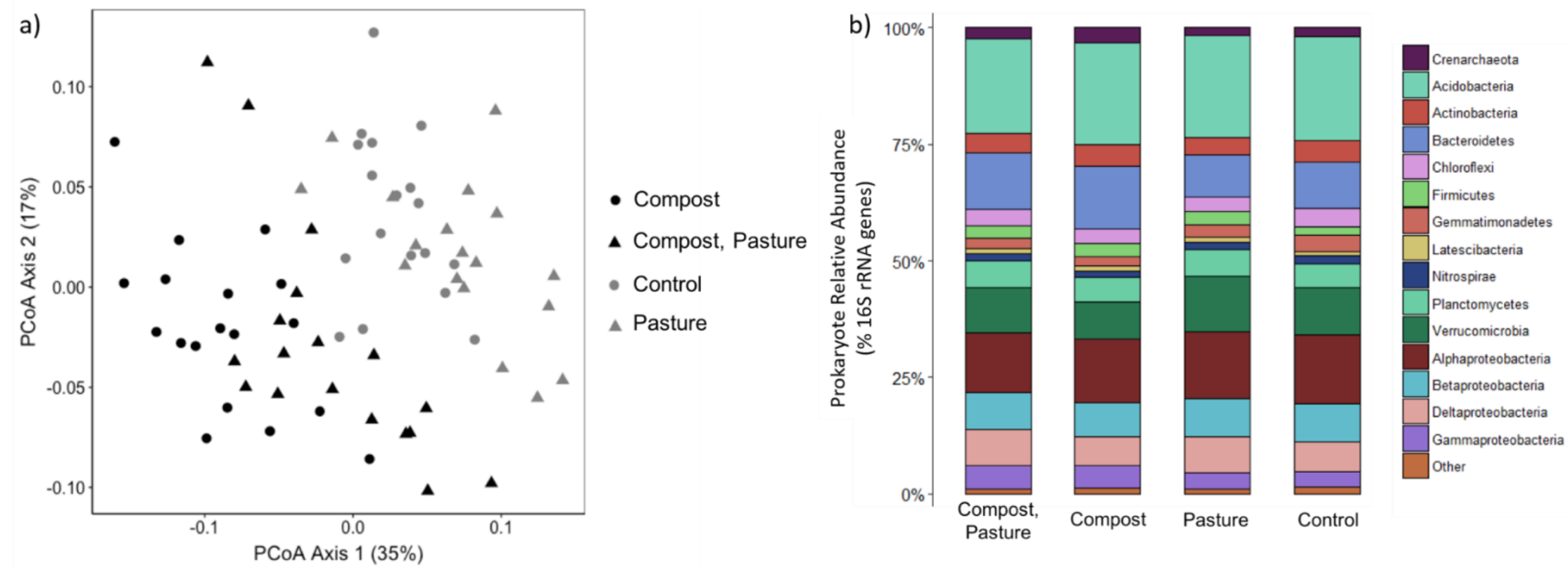

Figure 1: Effects of long term management on prokaryotic community composition (16S rRNA gene). Principle Coordinates Analysis (PCoA) using weighted Unifrac dissimilarity of community composition (a) and relative abundance (mean) of phyla and classes within Proteobacteria (b). 
a)

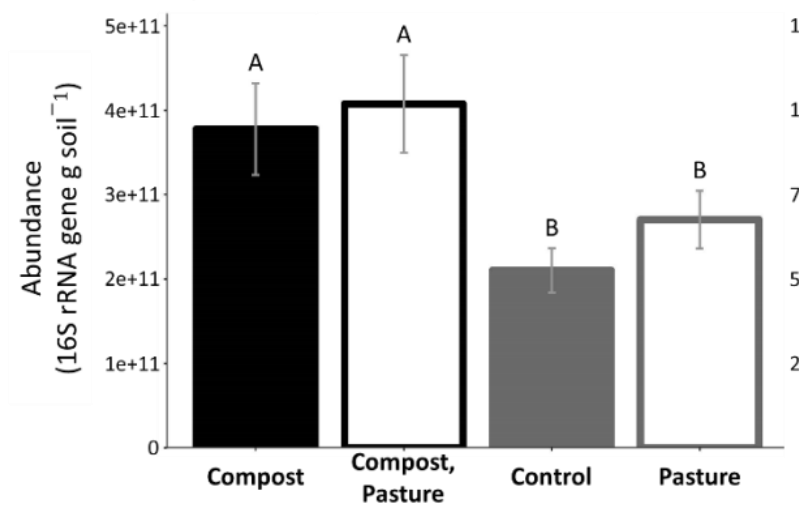

b)

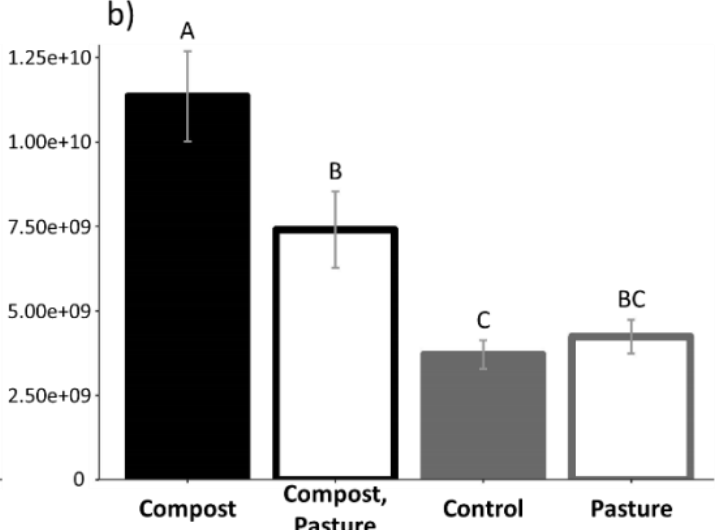

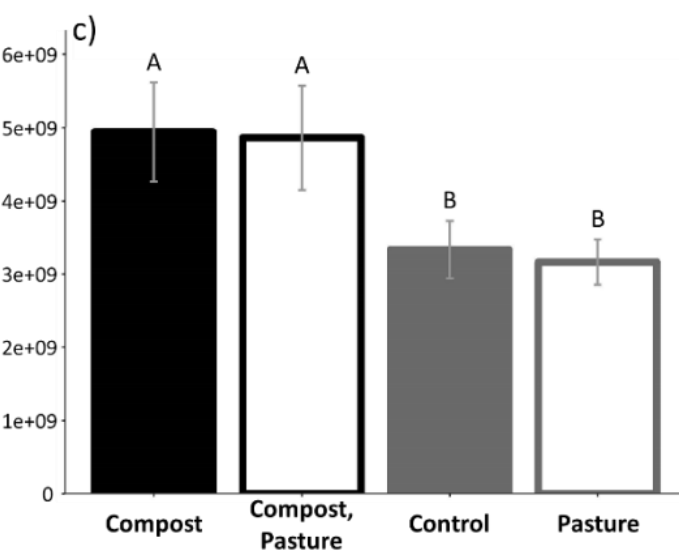

Figure 2: Abundance (mean \pm standard error) of $16 \mathrm{~S}$ rRNA genes from total prokaryotic community (a), putative ammonia oxidizing organisms (b), and putative nitrite oxidizing bacteria (c). Letters above bars indicates significantly different means resulting from compost addition (Tukey's HSD, $\alpha=0.05$ ). 

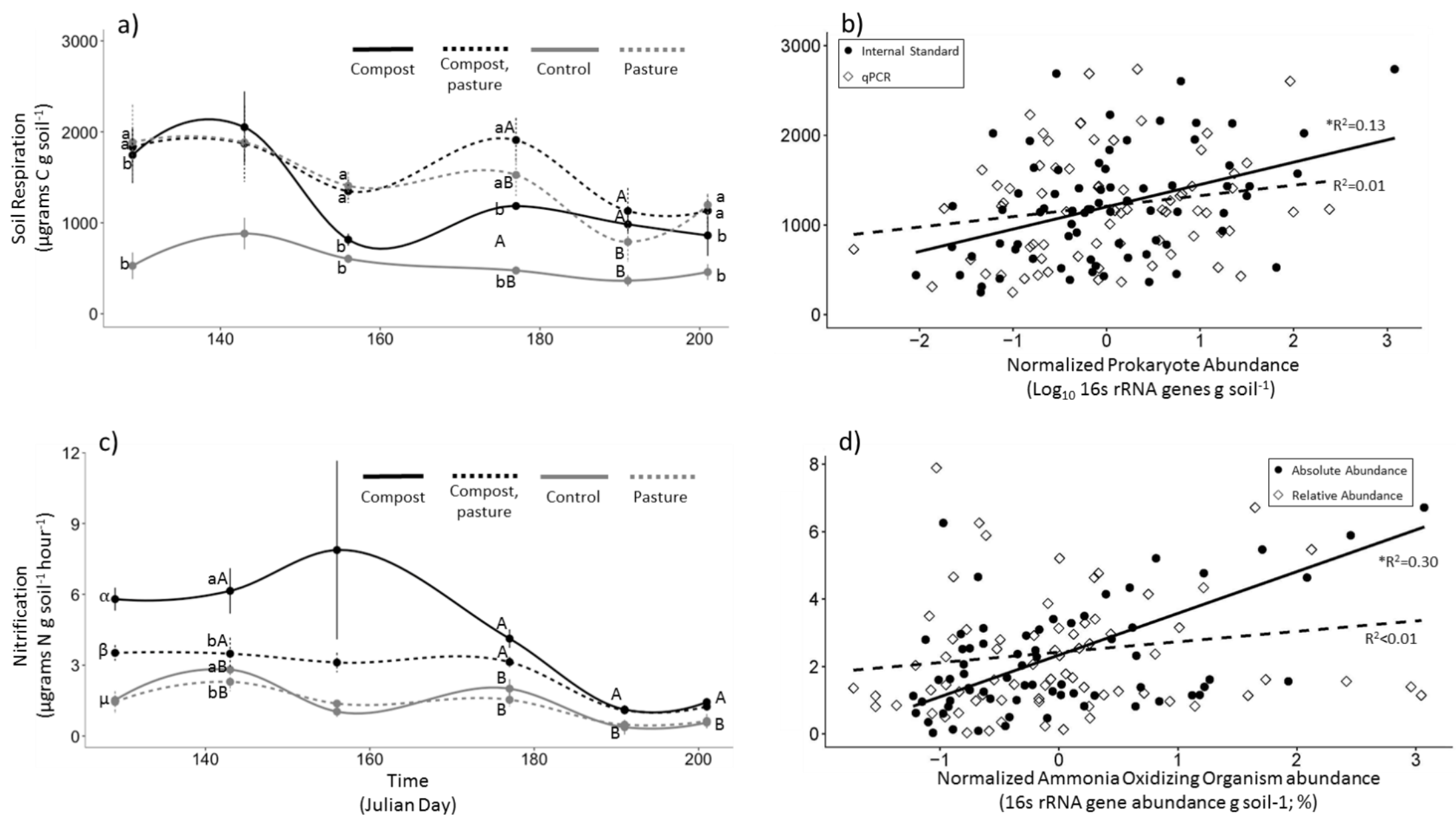

Figure 3: Effects on long term management on soil respiration rate (a) and potential nitrification rate (b) over time (mean \pm standard error). Regressions of respiration (b) and nitrification (d) rates with the abundances of corresponding microbial groups as determined via traditional approaches (unfilled circles) and the new internal standard method (filled circles). Letters indicate significantly different means (Tukey's HSD, $\alpha=0.05$ ) between compost (uppercase letters), pasture (lowercase letters), and interaction of compost and pasture (Greek letters) treatments at each time point. Asterisk $(*)$ indicate statistically significant adjusted $\mathrm{R}^{2}$ values $(\alpha=0.05)$. 

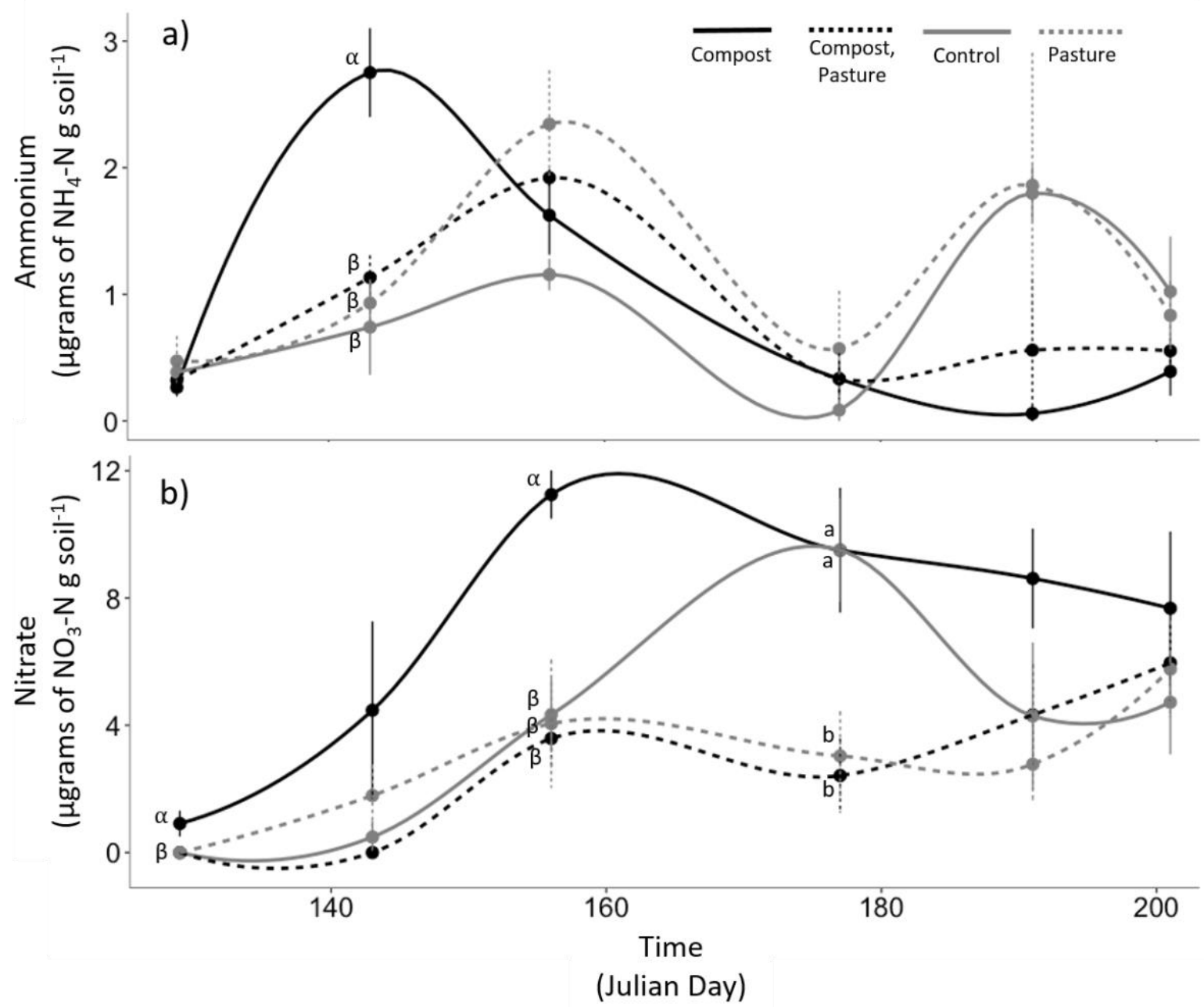

Figure 4: Soil ammonium (a) and nitrate (b) concentrations over time (mean \pm standard error). Letters indicate significantly different means (Tukey's HSD, $\alpha=0.05$ ) between compost (uppercase letters), pasture (lowercase letters), and interaction of compost and pasture (Greek letters) treatments within each time point. 


\section{References}

Abendroth, L. J., Elmore, R. W., Boyer, M. J., \& Marlay, S. K. (2011). Corn growth and development, Ext. Publ. PM 1009.

Bandick, A. K., \& Dick, R. P. (1999). Field management effects on soil enzyme activities. Soil biology and biochemistry, 31(11), 1471-1479.

Becel, C., Munier-Jolain, N. M., \& Nicolardot, B. (2015). Assessing nitrate leaching in cropping systems based on integrated weed management using the STICS soil-crop model. European Journal of Agronomy, 62, 46-54.

Bekku, Y., Koizumi, H., Nakadai, T., \& Iwaki, H. (1995). Measurement of soil respiration using closed chamber method: An IRGA technique. Ecological research, 10(3), 369-373.

Benoit, M., \& Garnier, J. (2014). Nitrogen leaching from organic agriculture and conventinal crop rotations. Building Organic Bridges, 1, 283-286.

Bolinder, M. A., Angers, D. A., Bélanger, G., Michaud, R., \& Laverdière, M. R. (2002). Root biomass and shoot to root ratios of perennial forage crops in eastern Canada. Canadian Journal of Plant Science, 82(4), 731-737.

Boot, R. G., \& Mensink, M. (1990). Size and morphology of root systems of perennial grasses from contrasting habitats as affected by nitrogen supply. Plant and Soil, 129(2), 291-299.

Ciampitti, I. A., \& Vyn, T. J. (2012). Physiological perspectives of changes over time in maize yield dependency on nitrogen uptake and associated nitrogen efficiencies: A review. Field Crops Research, 133, 48-67.

Caporaso, J. G., Lauber, C. L., Walters, W. A., Berg-Lyons, D., Lozupone, C. A., Turnbaugh, P. J., ... \& Knight, R. (2011). Global patterns of 16S rRNA diversity at a depth of millions of sequences per sample. Proceedings of the national academy of sciences, 108(Supplement 1), 4516-4522.

Cederlund, H., Wessén, E., Enwall, K., Jones, C. M., Juhanson, J., Pell, M., ... \& Hallin, S. (2014). Soil carbon quality and nitrogen fertilization structure bacterial communities with predictable responses of major bacterial phyla. Applied Soil Ecology, 84, 62-68.

Chan, K. Y., Conyers, M. K., Li, G. D., Helyar, K. R., Poile, G., Oates, A., \& Barchia, I. M. (2011). Soil carbon dynamics under different cropping and pasture management in temperate Australia: Results of three long-term experiments. Soil Research, 49(4), 320328.

Cruaud, P., Vigneron, A., Lucchetti-Miganeh, C., Ciron, P. E., Godfroy, A., \& CambonBonavita, M. A. (2014). Influence of DNA extraction methods, 16S rRNA targeted hypervariable regions and sample origins on the microbial diversity detected by 454 pyrosequencing in marine chemosynthetic ecosystems. Applied and environmental microbiology, AEM-00592.

Di, H. J., \& Cameron, K. C. (2002). Nitrate leaching in temperate agroecosystems: sources, factors and mitigating strategies. Nutrient cycling in agroecosystems, 64(3), 237-256. 
Diacono, M., \& Montemurro, F. (2011). Long-term effects of organic amendments on soil fertility. In Sustainable Agriculture Volume 2 (pp. 761-786). Springer, Dordrecht.

Drinkwater, L. E., \& Snapp, S. S. (2007). Nutrients in agroecosystems: rethinking the management paradigm. Advances in Agronomy, 92, 163-186.

Drinkwater, L. E., Wagoner, P., \& Sarrantonio, M. (1998). Legume-based cropping systems have reduced carbon and nitrogen losses. Nature, 396(6708), 262.

EPA (2011). Reactive nitrogen in the United States-an analysis of flows, consequences, and management options. EPA-SAB-11-013. Washington, DC: Environmental Protection Agency. https://yosemite.epa.gov/sab/sabproduct.nsf/WebBOARD/INCSupplemental?OpenDocu ment (accessed October $14^{\text {th }}, 2018$ )

Evanylo, G., Sherony, C., Spargo, J., Starner, D., Brosius, M., \& Haering, K. (2008). Soil and water environmental effects of fertilizer-, manure-, and compost-based fertility practices in an organic vegetable cropping system. Agriculture, ecosystems \& environment, 127(12), 50-58.

Frostegård, Å., Courtois, S., Ramisse, V., Clerc, S., Bernillon, D., Le Gall, F., ... \& Simonet, P. (1999). Quantification of bias related to the extraction of DNA directly from soils. Applied and environmental microbiology, 65(12), 5409-5420.

Hart, S. C., Stark, J. M., Davidson, E. A., \& Firestone, M. K. (1994). Nitrogen mineralization, immobilization, and nitrification. Methods of Soil Analysis: Part 2-Microbiological and Biochemical Properties, (methodsofsoilan2), 985-1018.

He, J. Z., Shen, J. P., Zhang, L. M., Zhu, Y. G., Zheng, Y. M., Xu, M. G., \& Di, H. (2007). Quantitative analyses of the abundance and composition of ammonia-oxidizing bacteria and ammonia-oxidizing archaea of a Chinese upland red soil under long-term fertilization practices. Environmental microbiology, 9(9), 2364-2374.

Jabloun, M., Schelde, K., Tao, F., \& Olesen, J. E. (2015). Effect of temperature and precipitation on nitrate leaching from organic cereal cropping systems in Denmark. European Journal of Agronomy, 62, 55-64.

Jia, Z., \& Conrad, R. (2009). Bacteria rather than Archaea dominate microbial ammonia oxidation in an agricultural soil. Environmental microbiology, 11(7), 1658-1671.

Johnston, A. E., Poulton, P. R., \& Coleman, K. (2009). Soil organic matter: its importance in sustainable agriculture and carbon dioxide fluxes. Advances in agronomy, 101, 1-57. 
Kozich, J. J., Westcott, S. L., Baxter, N. T., Highlander, S. K., \& Schloss, P. D. (2013). Development of a dual-index sequencing strategy and curation pipeline for analyzing amplicon sequence data on the MiSeq Illumina sequencing platform. Applied and environmental microbiology, 79(17), 5112-5120.

Lassaletta, L., Billen, G., Grizzetti, B., Anglade, J., \& Garnier, J. (2014). 50 year trends in nitrogen use efficiency of world cropping systems: the relationship between yield and nitrogen input to cropland. Environmental Research Letters, 9(10), 105011.

Leininger, S., Urich, T., Schloter, M., Schwark, L., Qi, J., Nicol, G. W., ... \& Schleper, C. (2006). Archaea predominate among ammonia-oxidizing prokaryotes in soils. Nature, 442(7104), 806.

Liu, B., Tu, C., Hu, S., Gumpertz, M., \& Ristaino, J. B. (2007). Effect of organic, sustainable, and conventional management strategies in grower fields on soil physical, chemical, and biological factors and the incidence of Southern blight. Applied Soil Ecology, 37(3), 202214.

Marinari, S., Mancinelli, R., Campiglia, E., \& Grego, S. (2006). Chemical and biological indicators of soil quality in organic and conventional farming systems in Central Italy. Ecological Indicators, 6(4), 701-711.

McLauchlan, K. K., Hobbie, S. E., \& Post, W. M. (2006). Conversion from agriculture to grassland builds soil organic matter on decadal timescales. Ecological applications, 16(1), 143-153.

McHugh, T. A., \& Schwartz, E. (2016). A watering manipulation in a semiarid grassland induced changes in fungal but not bacterial community composition. Pedobiologia, 59(3), 121-127.

Miranda, K. M., Espey, M. G., \& Wink, D. A. (2001). A rapid, simple spectrophotometric method for simultaneous detection of nitrate and nitrite. Nitric oxide, 5(1), 62-71.

Neubauer, S. C., Franklin, R. B., \& Berrier, D. J. (2013). Saltwater intrusion into tidal freshwater marshes alters the biogeochemical processing of organic carbon. Biogeosciences, 10(12), 8171.

Nolan, B. T., Hitt, K. J., \& Ruddy, B. C. (2002). Probability of nitrate contamination of recently recharged groundwaters in the conterminous United States. Environmental science \& technology, 36(10), 2138-2145.

Ouyang, Y., Norton, J. M., Stark, J. M., Reeve, J. R., \& Habteselassie, M. Y. (2016). Ammoniaoxidizing bacteria are more responsive than archaea to nitrogen source in an agricultural soil. Soil Biology and Biochemistry, 96, 4-15.

Pagliai, M., Vignozzi, N., \& Pellegrini, S. (2004). Soil structure and the effect of management practices. Soil and Tillage Research, 79(2), 131-143. 
Pang, X. P., \& Letey, J. (2000). Organic farming challenge of timing nitrogen availability to crop nitrogen requirements. Soil Science Society of America Journal, 64(1), 247-253.

Pena-Yewtukhiw, E. M., Romano, E. L., Waterland, N. L., \& Grove, J. H. (2017). Soil Health Indicators during Transition from Row Crops to Grass-Legume Sod. Soil Science Society of America Journal.

Ramirez, K. S., Lauber, C. L., Knight, R., Bradford, M. A., \& Fierer, N. (2010). Consistent effects of nitrogen fertilization on soil bacterial communities in contrasting systems. Ecology, 91(12), 3463-3470.

Romano, E. L., Pena-Yewtukhiw, E. M., Waterland, N. L., \& Grove, J. H. (2017). Soil Health Benefit to Composted Manure Application and Insertion of a Sod Component in a Longterm Organic Crop Rotation. Soil Science, 182(4), 137-145.

Russelle, M. P., Entz, M. H., \& Franzluebbers, A. J. (2007). Reconsidering integrated croplivestock systems in North America. Agronomy Journal, 99(2), 325-334.

Sinsabaugh, R. L., Carreiro, M. M., \& Repert, D. A. (2002). Allocation of extracellular enzymatic activity in relation to litter composition, $\mathrm{N}$ deposition, and mass loss. Biogeochemistry, 60(1), 1-24.

Schmidt, M. W., Torn, M. S., Abiven, S., Dittmar, T., Guggenberger, G., Janssens, I. A., ... \& Nannipieri, P. (2011). Persistence of soil organic matter as an ecosystem property. Nature, 478(7367), 49.

Smets, W., Leff, J. W., Bradford, M. A., McCulley, R. L., Lebeer, S., \& Fierer, N. (2016). A method for simultaneous measurement of soil bacterial abundances and community composition via 16S rRNA gene sequencing. Soil Biology and Biochemistry, 96, 145151.

Stopes, C., Lord, E. I., Philipps, L., \& Woodward, L. (2002). Nitrate leaching from organic farms and conventional farms following best practice. Soil Use and Management, 18, 256-263.

Thorup-Kristensen, K., Dresbøll, D. B., \& Kristensen, H. L. (2012). Crop yield, root growth, and nutrient dynamics in a conventional and three organic cropping systems with different levels of external inputs and $\mathrm{N}$ re-cycling through fertility building crops. European Journal of Agronomy, 37(1), 66-82.

Tracy, B. F., \& Zhang, Y. (2008). Soil compaction, corn yield response, and soil nutrient pool dynamics within an integrated crop-livestock system in Illinois. Crop Science, 48(3), 1211-1218.

Tu, C., Ristaino, J. B., \& Hu, S. (2006). Soil microbial biomass and activity in organic tomato farming systems: Effects of organic inputs and straw mulching. Soil Biology and Biochemistry, 38(2), 247-255.

USDA NRCS. (2012). Census of Agriculture. www.agcensus.usda.gov/ (accessed October 14 ${ }^{\text {th }}$, 2018)

USDA ERS. (2013). Agriculture resource management survey (ARMS). https://www.ers.usda.gov/ (accessed October 14th, 2018) 
Veihmeyer, F. J., \& Hendrickson, A. H. (1949). Methods of measuring field capacity and permanent wilting percentage of soils. Soil science, 68(1), 75-94.

Wüst, P. K., Nacke, H., Kaiser, K., Marhan, S., Sikorski, J., Kandeler, E., ... \& Overmann, J. (2016). Estimates of soil bacterial ribosome content and diversity are significantly affected by the nucleic acid extraction method employed. Applied and environmental microbiology, 82(9), 2595-2607.

Zeng, J., Liu, X., Song, L., Lin, X., Zhang, H., Shen, C., \& Chu, H. (2016). Nitrogen fertilization directly affects soil bacterial diversity and indirectly affects bacterial community composition. Soil Biology and Biochemistry, 92, 41-49.

Zhalnina, K., Dörr de Quadros, P., AO Camargo, F., \& Triplett, E. W. (2012). Drivers of archaeal ammonia-oxidizing communities in soil. Frontiers in microbiology, 3, 210.

Zhou, J., Jiang, X., Wei, D., Zhao, B., Ma, M., Chen, S., ... \& Li, J. (2017). Consistent effects of nitrogen fertilization on soil bacterial communities in black soils for two crop seasons in China. Scientific reports, 7(1), 3267. 
Appendix 1. Miscanthus residue amendment experiment.

This experiment was designed to test the potential for the addition of Miscanthus $x$ giganteus (Miscanthus) residue to stimulate microbial immobilization of nitrogen when applied in combination with composted dairy manure. Plots from the OCLF experiment that were planted with maize and amended with compost as part of the long term treatment experiment were split and half of the plots received chopped miscanthus residue at a rate of $2000 \mathrm{lbs}$. dry matter ac ${ }^{-1}$, which was tilled into the soil with the incorporation of compost and cover crops. Each half of the split plots was treated as a separate plot and soil samples were collected on the same schedule and the same analyses performed as for the long-term experiment. All environmental, microbial activity, and microbial community parameters were determined as described in the methods.

Table A1 -1. Results of Miscanthus residue amendment experiment. *

\begin{tabular}{|c|c|c|c|}
\hline & Compost & Miscanthus & Control \\
\hline \multicolumn{4}{|l|}{ Environmental Parameters } \\
\hline $\mathrm{pH}$ & $7.3(0.1)$ & $7.3(0.1)$ & $7.4(0.1)$ \\
\hline Organic Matter (\%) & $7.9(0.3)$ & $8.3(0.3)$ & $5.6(0.1)$ \\
\hline Soil Moisture (\%) & $41.2(1.6)$ & $41.8(1.7)$ & $45.4(2.6)$ \\
\hline Field Capacity (g water g soil ${ }^{-1}$ ) & $0.7(0)$ & $0.8(0)$ & $0.6(0)$ \\
\hline \multicolumn{4}{|l|}{ Soil Inorganic Nitrogen $\left(\mu\right.$ grams g soil $\left.^{-1}\right)$} \\
\hline Ammonium & $0.9(0.2)$ & $1(0.3)$ & $0.9(0.2)$ \\
\hline Nitrate & $7.1(1)$ & $6.8(1.8)$ & $3.9(0.9)$ \\
\hline Total & $8(1.1)$ & $7.8(1.8)$ & $4.8(0.9)$ \\
\hline \multicolumn{4}{|l|}{ Microbial Activity } \\
\hline Potential Nitrification ( $\mu$ grams $\mathrm{N} \mathrm{g} \mathrm{soil}^{-1} \mathrm{hr}^{-1)}$ & $4.4(0.8)$ & $3.8(0.7)$ & $1.4(0.2)$ \\
\hline Soil Respiration ( $\mu$ grams $\mathrm{C}$ g soil ${ }^{-1} \mathrm{hr}^{-1)}$ & $1273(137)$ & $1821(310)$ & $552(53)$ \\
\hline \multicolumn{4}{|l|}{ Enzyme Activities (pmol g soil ${ }^{-1} \mathrm{hr}^{-1}$ ) } \\
\hline Potential BG & $18.6(1.9)$ & $26.2(1.8)$ & $10.4(1)$ \\
\hline Potential CBH & $3.6(0.6)$ & $4.7(0.5)$ & $2.2(0.5)$ \\
\hline Potential LAP & $6.4(0.4)$ & $8.3(0.8)$ & $4.3(0.6)$ \\
\hline \multicolumn{4}{|l|}{ Microbial Community } \\
\hline AOO Relative Abundance $(\%)$ & $3.2(0.3)$ & $3(0.3)$ & $1.9(0.1)$ \\
\hline NOB Relative Abundance (\%) & $1.4(0.1)$ & $1.4(0.1)$ & $1.6(0.1)$ \\
\hline \multicolumn{4}{|c|}{ Microbial Gene Abundance ( $\log _{10} 16$ s rRNA genes g soil $\left.{ }^{-1}\right)$} \\
\hline qPCR Total Prokaryote & $8.6(0)$ & $8.6(0)$ & $8.4(0)$ \\
\hline IS Total Prokaryote & $11.6(0.1)$ & $11.7(0.1)$ & $11.3(0.1)$ \\
\hline AOO Absolute & $10(0.1)$ & $10.1(0.1)$ & $9.6(0)$ \\
\hline NOB Absolute & $9.7(0.1)$ & $9.8(0.1)$ & $9.5(0.1)$ \\
\hline
\end{tabular}

* Data are presented as mean ( \pm standard error) of $\mathrm{pH}$, organic matter, soil moisture, field capacity, ammonium, nitrate, and total mineral nitrogen concentration, potential nitrification rate, soil respiration, potential beta-1-4glucosidase (BG), 1-4-beta-cellobiosidase (CBH), and Lleucine aminopeptidase (LAP) enzyme activity, relative abundance of ammonia oxidizing organisms (AOO) and nitrite oxidizing bacteria (NOB), total prokaryote abundance measured by qPCR and the internal standard (IS) method, and absolute abundance of AOO and NOB. 